\title{
Evaluation of Hydrocarbon Potential in the Jahrom Area, Interior Fars, Zagros
}

\author{
Mehdi Hosseinpour ${ }^{1,2}$, Zahra Maleki ${ }^{1,2 *}$, Mohsen Aleali ${ }^{1,2}$ \\ ${ }^{1}$ Department of Petroleum Engineering, Science and Research Branch, Islamic Azad University, Tehran, Iran \\ ${ }^{2}$ Department of Geology, Science and Research Branch, Islamic Azad University, Tehran, Iran \\ Email: ${ }^{\star}$ z.maleki@srbiau.ac.ir
}

How to cite this paper: Hosseinpour, $M$. Maleki, Z. and Aleali, M. (2017) Evaluation of Hydrocarbon Potential in the Jahrom Area, Interior Fars, Zagros. Open Journal of Geology, 7, 429-442. https://doi.org/10.4236/ojg.2017.73029

Received: September 10, 2016

Accepted: March 28, 2017

Published: March 31, 2017

Copyright (c) 2017 by authors and Scientific Research Publishing Inc. This work is licensed under the Creative Commons Attribution International License (CC BY 4.0).

http://creativecommons.org/licenses/by/4.0/

cc) (i) Open Access

\begin{abstract}
The study area is located in the Fars area (Interior Fars sub-basin). This area, which is part of the Zagros fold-thrust belt, is located in Zagros simple folded sub zone. It is known as one of the most important regions in the world Gas rich. In this area, anticlinal folds are a different orientation of such as the North Western-South Eastern, East-West and North Eastern-South Western. The Karbasi and Khaftar anticlines are case study anticlines in the interior Fars sub-basin (Fassa area). The anticlines in the Fars region, which are located in the Zagros fold-thrust belt, are valuable because they possess several hydrocarbons. The main aim of this paper is evaluation of hydrocarbon potential in the Jahrom area (Interior Fars) based on interpretation of the Isopach maps and well data. This paper presents part of the results of a regional study of the Coastal Fars area in the Zagros Simply folded belt, based on original fieldwork, satellite images, structural sections, geological maps and well data. In order to investigate of periods Nezamabad fault activity, Isopach maps of the study area has been prepared based on well drilling data and the thickness of the drilled formations. In this study utilizes the thickness of the drilled formations in the study area, for each sedimentary unit was carried out to prepare Isopach maps. The Isopach map prepared based on GIS software method and exploration well data. The Nezamabad fault has been lacked of activity at the deposition time of the Dalan, Kangan, Dashtak, Fahliyan, Gadvan, Dariyan, Kazhdomi, Sarvak, Gurpi and Pabdeh formations within the Khaftar and Karbasi anticline area. Accordingly, changes in basin floor, at the time of sedimentation these formations has not been affected by the Nezamabad fault. Probably the Nezamabad fault has been activated during deposition of the Surmeh, Hith, Laffan and Ilam formations and in this area paleo-basin has been controlled by this fault. In other words, it seems that, activity of the Nezamabad fault in this area have been limited to Jurassic and Cretaceous periods (Coniacian and Senomanian). This can means that in this periods time, the Nezamabad fault have been active sedimentation along with tectonic
\end{abstract}


processes and activities affected on thickness of the Surmeh, Hith, Laffan and Ilam formations. Finally, it seems that the Nezamabad Fault activity has been affected on the source rock, reservoir rock and cap rock and then controlled distributing of hydrocarbon System of the study area in the Khaftar and Karbasi as anticlinal oil traps.

\section{Keywords}

Hydrocarbon Potential, Jahrom Area, Nezamabad Fault, Interior Fars, Zagros

\section{Introduction}

Hydrocarbon Reservoirs in the Middle East are mainly Mesozoic age; the structural traps, carbonate reservoir rock, reservoir depth average (less than $5.4 \mathrm{~km}$ ) and exploration have been in the past 60 years. The Zagros fold-thrust belt located among the Himalayan-Alpine orogenic belt caused by the collision of the Eurasian plate Arabian plate with the Eurasian plate slips Arabic has been created [1]. Focus multiple source rocks and rich in organic matter Organic materials, porous and permeable reservoir rocks with good cap rock reservoir rocks with well Porosity and permeability including appropriate cap rock in this area has provided a unique conditions for the production and accumulation of hydrocarbons Production and accumulation of hydrocarbons [2].

The study area is located in the Fars area (Interior Fars sub-basin). This area, which is part of the Zagros fold-thrust belt, is located in Zagros simple folded sub zone. It is known as one of the most important regions in the world Gas rich. In this area, anticlinal folds are a different orientation of such as the North Western-South Eastern, East-West and North Eastern-South Western. Change the orientation of axis anticline in this area can be show the activity of basement faults. In addition, this case can relate to the rotation vector of Arabian Plate to Iranian plate [3].

According to the existence of many active faults in Interior Fars area, faults may be considered as a major factor control on the distribution of hydrocarbon traps in the area. Including main faults in this region are the Nezamabad fault (Figure 1) with the northeast-southwest trend with length about $265 \mathrm{~km}$ that begins southern flank of the Shahini anticline and continues to the southeast Neyriz area. This fault has been introduced for the first time by Barzegar (1994), based on remote sensing. The study area is located in the Zagros Simply Folded Belt of Iran and in the Fars province. The Karbasi and Khaftar anticlines are case study anticlines in the interior Fars sub-basin (Fassa area). The anticlines in the Fars region, which are located in the Zagros fold-thrust belt, are valuable because they possess several hydrocarbons. Some researchers have been studied on the structural style and hydrocarbon traps in the Fars area [4]-[15]. In this research, the main aim of this paper is Evaluation of hydrocarbon potential in the Jahrom area (Interior Fars) based on interpretation of the Isopach maps and well 
data.

\section{Material and Methods}

This paper presents part of the results of a regional study of the Coastal Fars area in the Zagros Simply folded belt, based on original fieldwork, satellite images, structural sections, geological maps and well data. In order to investigate of periods Nezamabad fault activity, Isopach maps of the study area has been prepared based on well drilling data and the thickness of the drilled formations. In this study utilizes the thickness of the drilled formations in the study area, for each sedimentary unit was carried out to prepare Isopach maps. The Isopach map prepared based on GIS software (Version 10.4.1) method.

\section{Geological Setting and Stratigraphy}

The Zagros orogenic belt is located from Anatolian Eastern fault to Oman lineament in South of Iran and has Northwest-Southeast trend and this belt [16]. The Zagros belt as fold-thrust belt is limited from North boundary with Iran plate and from South boundary with Northeastern edge of Arabian plate. In this area, the continental-continental plates as Convergent boundary form the Iranian and Arabian-African plates. These parts from upper cretaceous have been formed as the Zagros orogenic belt and this convergent continuous up to now. This convergent has created consequent to close the Neotethys [16]. The Zagros

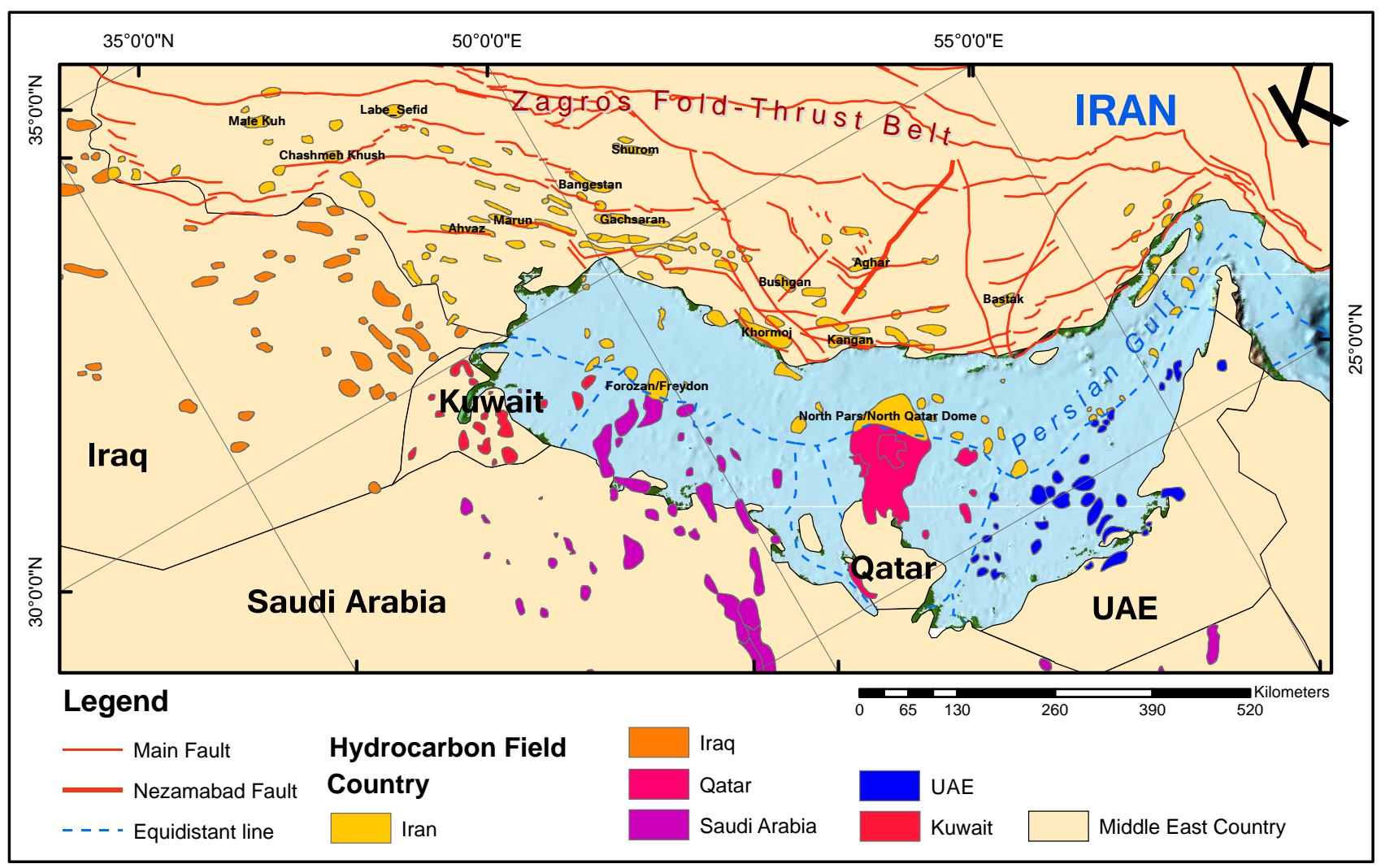

Figure 1. The distribution map of hydrocarbon reservoirs in the Zagros fold-thrust belt. 
orogenic belt is located from Anatolian Eastern part toward Oman line in South of Iran [17] [18] [19] and has $200-300 \mathrm{~km}$ width and this belt.

The main dominant structures in the Zagros fold-thrust belt have folds and thrusts with Northwestern-Southeastern trend. These structures has main tendency toward Southwestern. Based on morphology view, this belt is divided to High Zagros and Folded Zagros. This belt has average height of near to 1200 meters. According to structural classification, the Zagros fold-thrust belt from Northeastern to Southeastern is divided to; High Zagros Thrust Belt, Simply Folded Belt, Zagros Foredeep and Coastal Plane [16] [18] [20] [21]. Based on facies changes, the Zagros fold-thrust belt divided to Lurestan basin (Northwestern of Zagros), Khuzestan basin (Central Zagros) and Fars basin (Southeastern of Zagros) from Northwestern to Southeastern. The study area is located in the Fars basin and this area belongs to the Fars basin. This Basin has three parts contain the Interior Fars, External Fars and Bandar Abbas hinterland. The External Fars has subdivided; Costal Fars and Sub-Costal Fars [20]. Based on geological facies units perpendicular to the Zagros belt, the Fars geological province in this belt has divided into the Interior Fars, Sub-Coastal and Coastal Fars sub-basins [20]. According this case, the study area is located in the Coastal Fars sub-basin or Fars Platform (Figure 2, Figure 3). The significant geological characteristics in the Fars area are:

- The Fars area has platform conditions based on sedimentary facies and stratigraphic characteristics. This case has caused continuity of Arabian basement from the Qatar to the Fars area. This part has been entitled the Gavbandi Paleo-high [20].

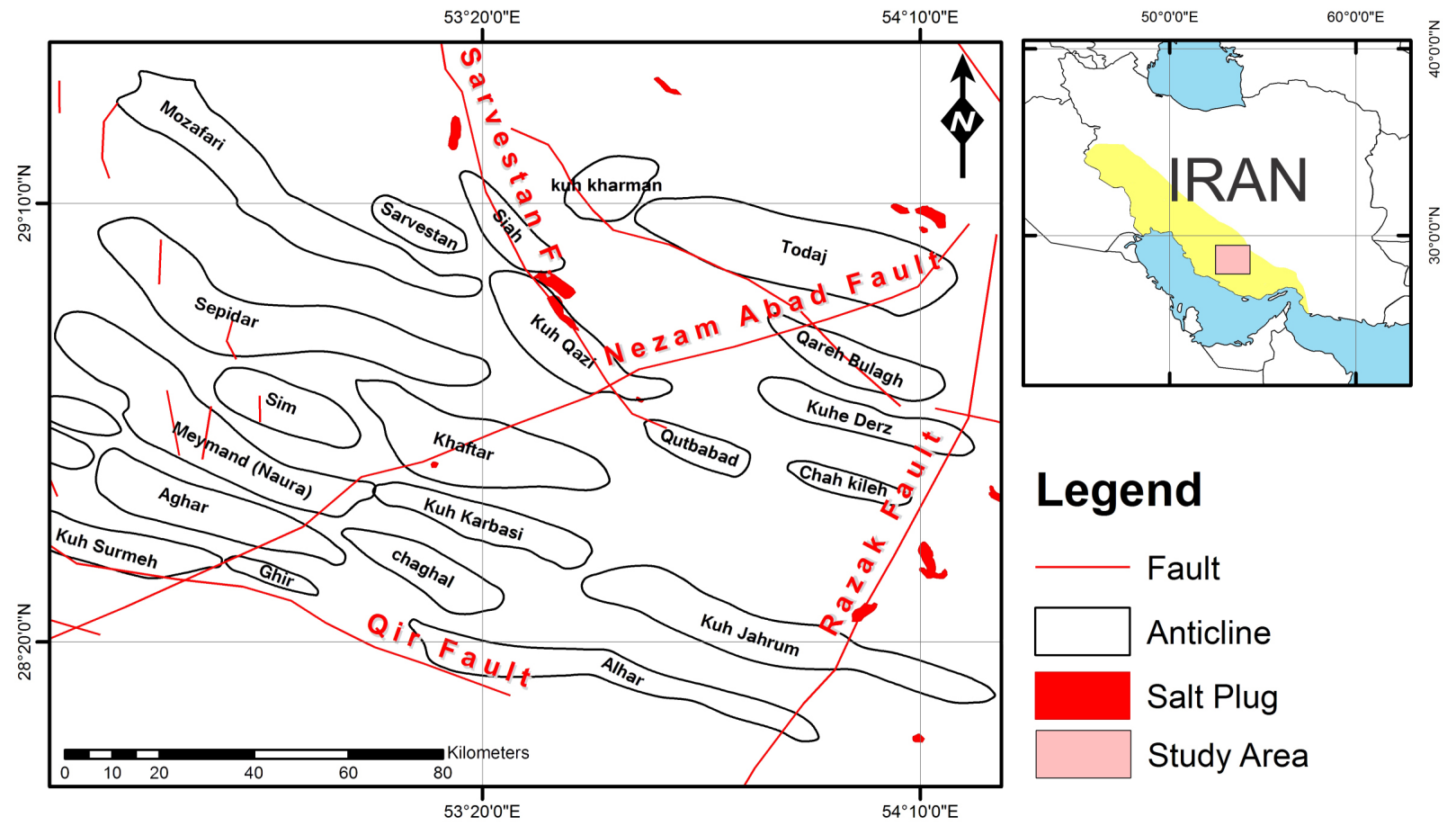

Figure 2. The study area and location of anticlines, salt plugs and maim faults. 


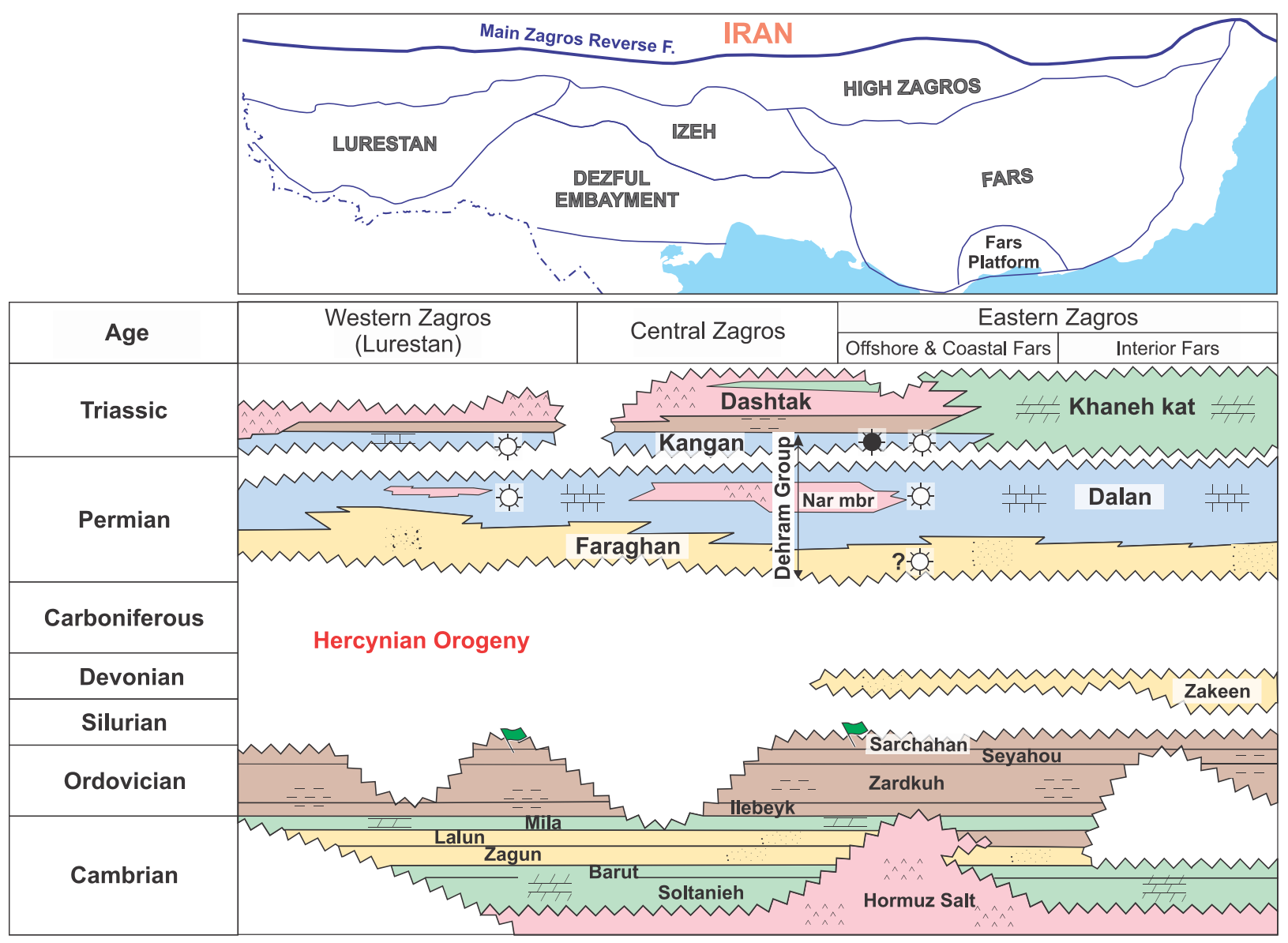

Figure 3. The stratigraphic column of the Zagros fold-thrust belt. The Source-rocks areindicated with Green flag,Gas reservoirs with white sun mark and oil reservoirs with black sun mark (modified after Motiei, 1993 [20] by Esrafili-Dizaji and Rahi-mpourBonab, $2013[21])$.

- The anticlinal structures have various trends such as Eastern-Western, Northwestern-Southeastern and some of these anticlines have NortheasternSouthwestern trend. The basement faults activity have caused or rotated of Arabian plate to Iranian plate on the structures trends. The folding pattern in the Fars area has concentric style. In this area, main decollement unit is Hormoz series and minor decollements are the Dashtak Formation evaporites, Gurpi and Pabdeh Formation Shales.

The Khaftar and Karbasi anticlines are located in the Interior Fars region (Fasa area). Trend of the Khaftar anticline has three orientations consisting NorthNortheast, East-West and South-Southwest. This anticline is bounded from north by Kuh-e Qazi anticline, from north-northeast by Qutbabad anticline, from south-southeast by the Karbasi anticline and from southwest by Sim anticlines (Figure 2). The trend of the Karbasi anticline is $\mathrm{N} 60^{\circ} \mathrm{W}$. This anticline is bounded from south by the Chaghal, from southwest by the Noura, from northnortheast by the Khaftar and from north-northeast by the Jahrom anticlines (Figure 2). The Karbasi anticline is an elongated structure with $40 \mathrm{~km}$ length 
and $7.5 \mathrm{~km}$ width in the Asmari horizon. The Khaftar anticline is an asymmetric structure with $45 \mathrm{~km}$ length and $12.5 \mathrm{~km}$ width in the Asmari horizon on the surface (Figure 4).

\section{Evaluation of Hydrocarbon Potential in the Jahrom Area}

The Zagros fold-thrust belt is located in the Alpine-Himalayan mountain belt that has been created by the collision of the Eurasian plate with Arabian plate [1]. Focus of multiple source rocks and very rich in organic matter, porous and permeable reservoir rocks with good cap rock in this area has provided unique conditions for the production and accumulation of hydrocarbons in the region [2]. Fars region is part of the Zagros simply folded sub-basin that has about 15 percent of the world's gas reserves [22]. In this study, the Nezamabad fault effect on deposition of formations in the external Fars region was chosen as a case study. Then with providing the Isopach maps for source, reservoir rocks and cap rock in the external Fars region to identify the Nezamabad fault effect and basin modeling during deposition of the formations, being successful, being economic and or non-economic of drilling in anticlines adjacent the fault will be discussed. The source rock, reservoir and cap rock as key factors are considered in the exploration of hydrocarbon resources. Therefore, that accurate recognition of each of them, along with the changes occurred, causing different functions. Therefore, that it can cause changes and evolution of the nature of a hydrocarbon system. Such as effective parameters, it can be noted that the activity of basement faults and its effect on hydrocarbon systems. Because of basement faults, can play the
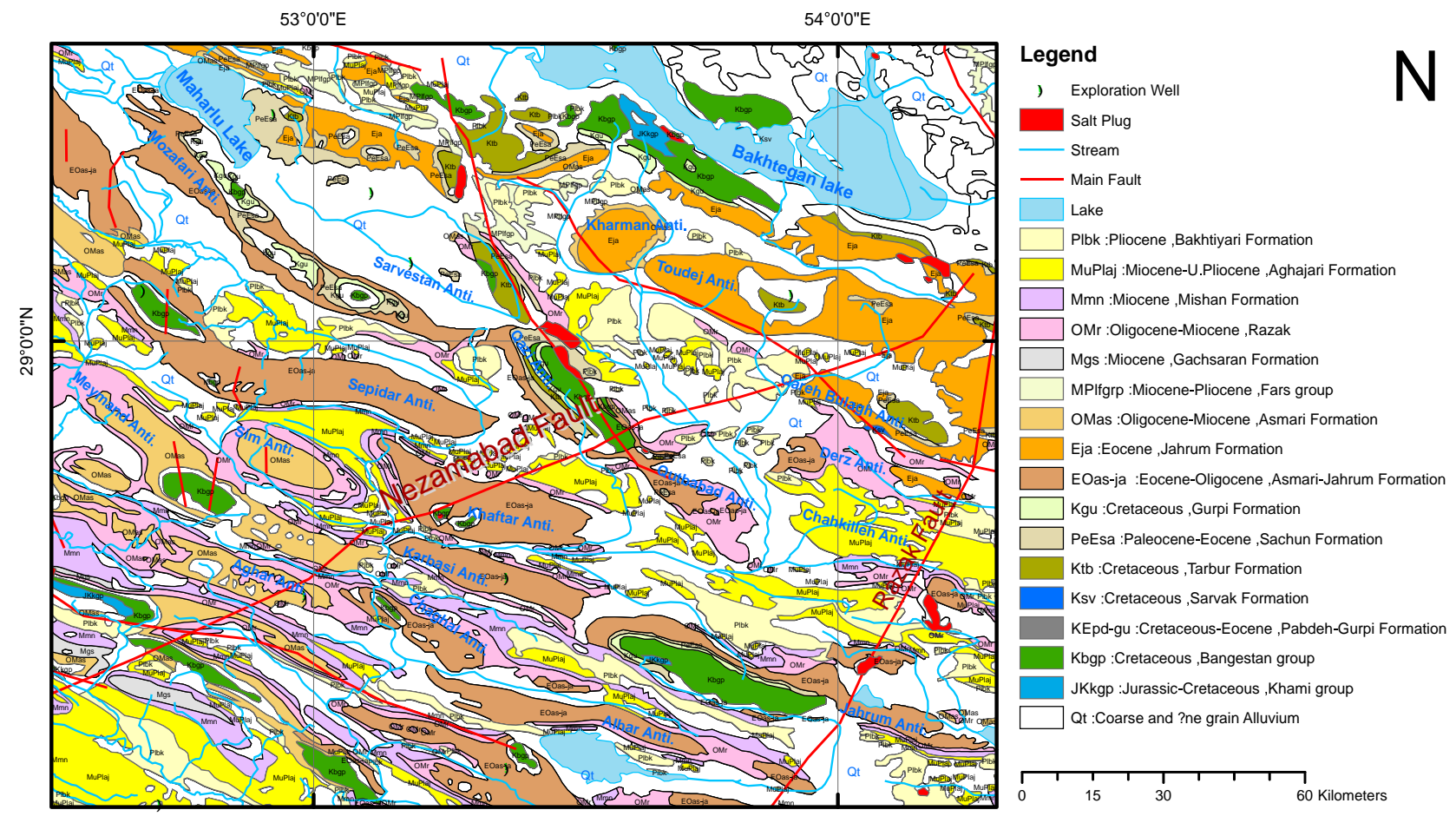

Figure 4. Geological map of the study area. 
role constructive or destructive in the production and accumulation of hydrocarbons. Based on these case, in this research we have investigation of the Evaluation hydrocarbon potential in the Jahrom area by prepared Isopach maps of the Jahrom area and interpretation these maps via exploration well data.

\subsection{Dalan and Kangan Formations}

The Dalan Formation with Upper Permian age is as the important reservoir horizon in the Fars area of the Zagros fold-thrust Belt. In the study area, thickness of this formation varies from $760 \mathrm{~m}$ to $800 \mathrm{~m}$ especially in the Khaftar and Karbasi anticlines. According to thickness variations Isopach map of the Dalan horizon, it seems that the Nezamabad fault has been inactive at the time of upper Permian as the main fault in the study area (Figure 5).

The Kangan and Dalan formations have created a reservoir horizon of the Dehram is known as Gas rich reservoir in the Fars province. According to studies, the thickness of this formation is the same in the Isopach map anticlines Karbasi and Khaftar. It seems tectonic processes have been inactive during Kangan sedimentation of the Formation and in the Early Triassic time. Accordingly, also the fault has been not Nezamabad activity in the area (Figure 5).

\subsection{Dashtak Formation}

The Dashtak formation is as significant cap rock, for Dehram Groups reservoirs in the Fars area. Thickness of this formation in the study area has been increased from West to East. According to the curves of Isopach map, which are as non-parallel to the Nezamabad fault, it seems that this fault has not been activated at Middle Triassic time (Figure 5).

\subsection{Surmeh Formation}

The Surmeh Formation (Upper Middle Jurassic) there is a wide range distribution in the Fars area. This formation in the study area has variations thickness from 760 to 900 meters. The maximum and minimum thickness of this formation exists in the northwestern part of the Khaftar anticline and in the southeastern part the Karbasi anticline (Figure 5).

\subsection{Hith Formation}

It seems that activity the Nezamabad fault has been begun from Jurassic and continued to Jurassic Late. Probably active faults and tectonic processes has led to uplift of the basin has been provided in the anticlines Karbasi and Khaftar and conditions of accumulation evaporite sediments and sedimentation of the Formation Hith. The Curves Isopach parallel with the fault the Nezamabad within Khaftar and Karbasi anticlines can be indicative of fault activity Nezamabad (Figure 6).

\subsection{Fahlian Formation}

Based on prepared Isopach map, Fahlian Formation thickness has been in- 
creased from south to north and to the northeast (Figure 6). The Northeast of the study area has a maximum thickness of this formation and it seems that basin has been located in the deeper part of the study area. According to Isopach map, Isopach curves is non-parallel with the Nezamabad fault, therefore, it seems that the Nezamabad fault has been inactive at the time of deposition of Fahlian formation (Figure 6).

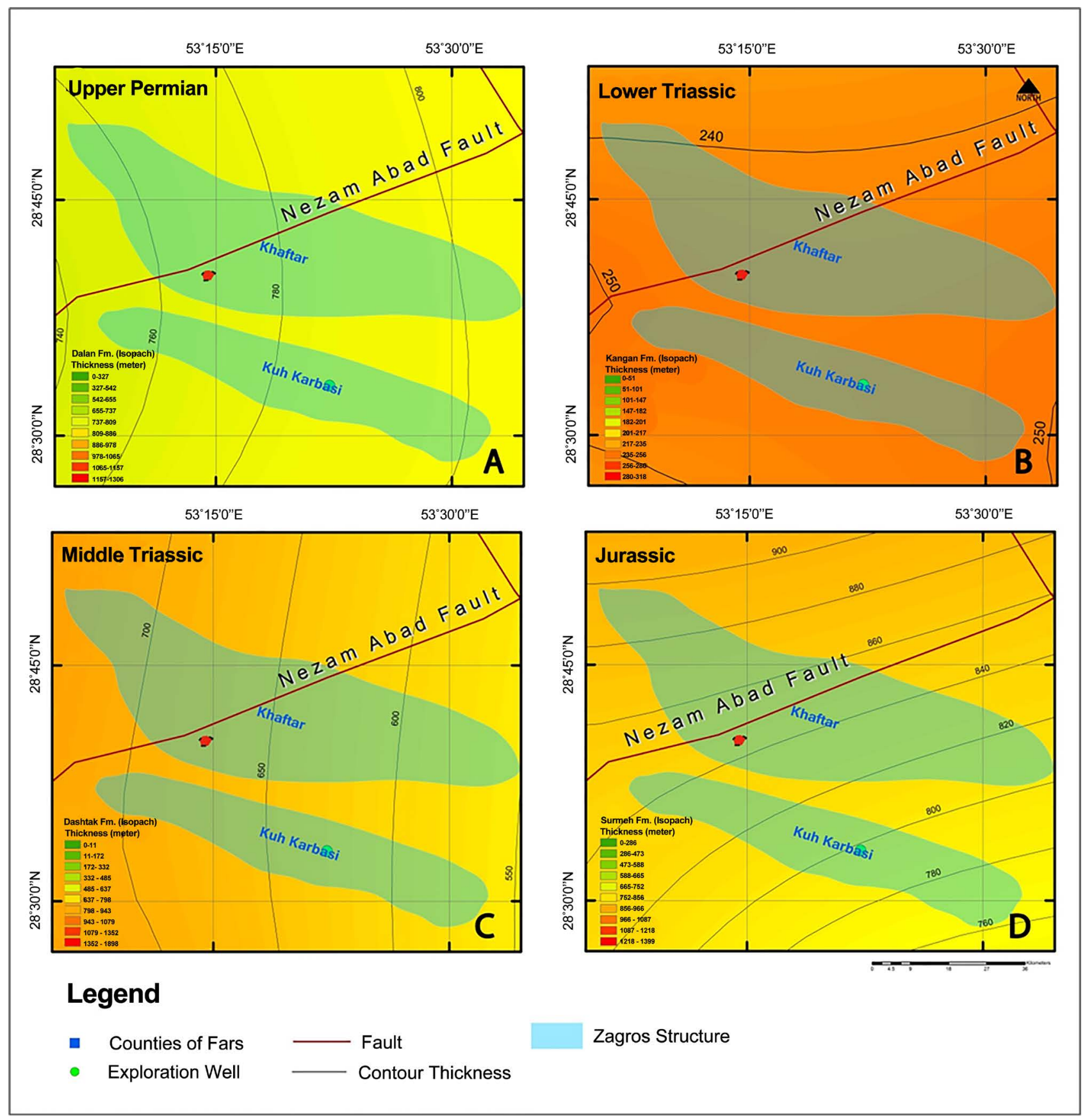

Figure 5. Isopach maps of formations in the study area, the Khaftar and Karbasi anticlines (from Upper Permian to Jurassic): (A) Isopach Map of the Dalan Formation (upper Permian); (B) Isopach map the Kangan Formation (lower Triassic); (C) Isopach map of the Dashtak Formation (Middle Triassic); (D) Isopach map of the Surmeh Formation (Jurassic). 


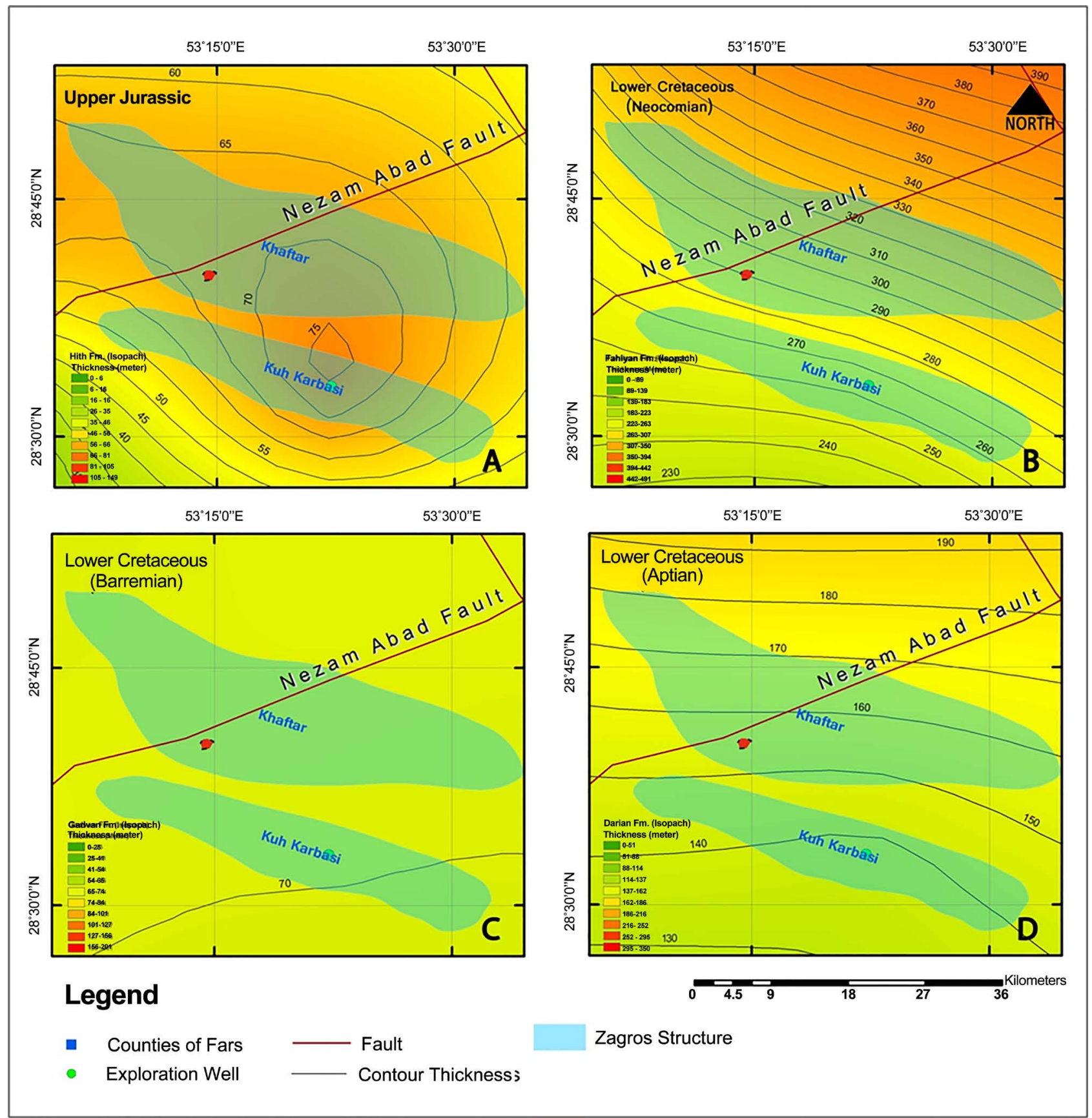

Figure 6. Isopach maps of formations in the study area, the Khaftar and Karbasi anticlines (from Upper Jurassic to Lower Cretaceous (Aptian): (A) Isopach Map of the Hith Formation (Upper Jurassic); (B) Isopach map the Fahliyan Formation (Lower Cretaceous, Neocomian); (C) Isopach map of the Gadvan Formation (Lower Cretaceous, Barremian); (D) Isopach map of the Surmeh Formation (Lower Cretaceous, Aptian).

\subsection{Gadvan and Dariyan Formations}

The Gadvan Formation with Barmiyan ageis considered the source rock for Dariyan horizon. Based on Isopach map, it seems that the basin has been conditions similar depth during deposition of this formation in the Khaftar and Karbasi anticlines. Therefore, the Nezamabad fault fault is has been inactive Nezamabad (Figure 6). 


\subsection{Kazhdomi, Sarvak, Laffan and Ilam Formations}

The Nezamabad fault inactivity has been continued during the sedimentation Kazhdomi and Sarvak formations. However, the reactivation of the Nezamabad fault has been begun in the Upper Cretaceous (Coniacian Stage and Santonian Stage). In the study area, activity fault atthis timehas been led to variation thickness of the Laffan and Ilam Formations. The thickness Curves in the Isopach map is parallel with trend of the Nezamabad fault and changes in thickness around this fault can be attributed to activity of the Nezamabad fault begun in the Upper Cretaceous (Coniacian Stage and Santonian Stage) (Figure 7).
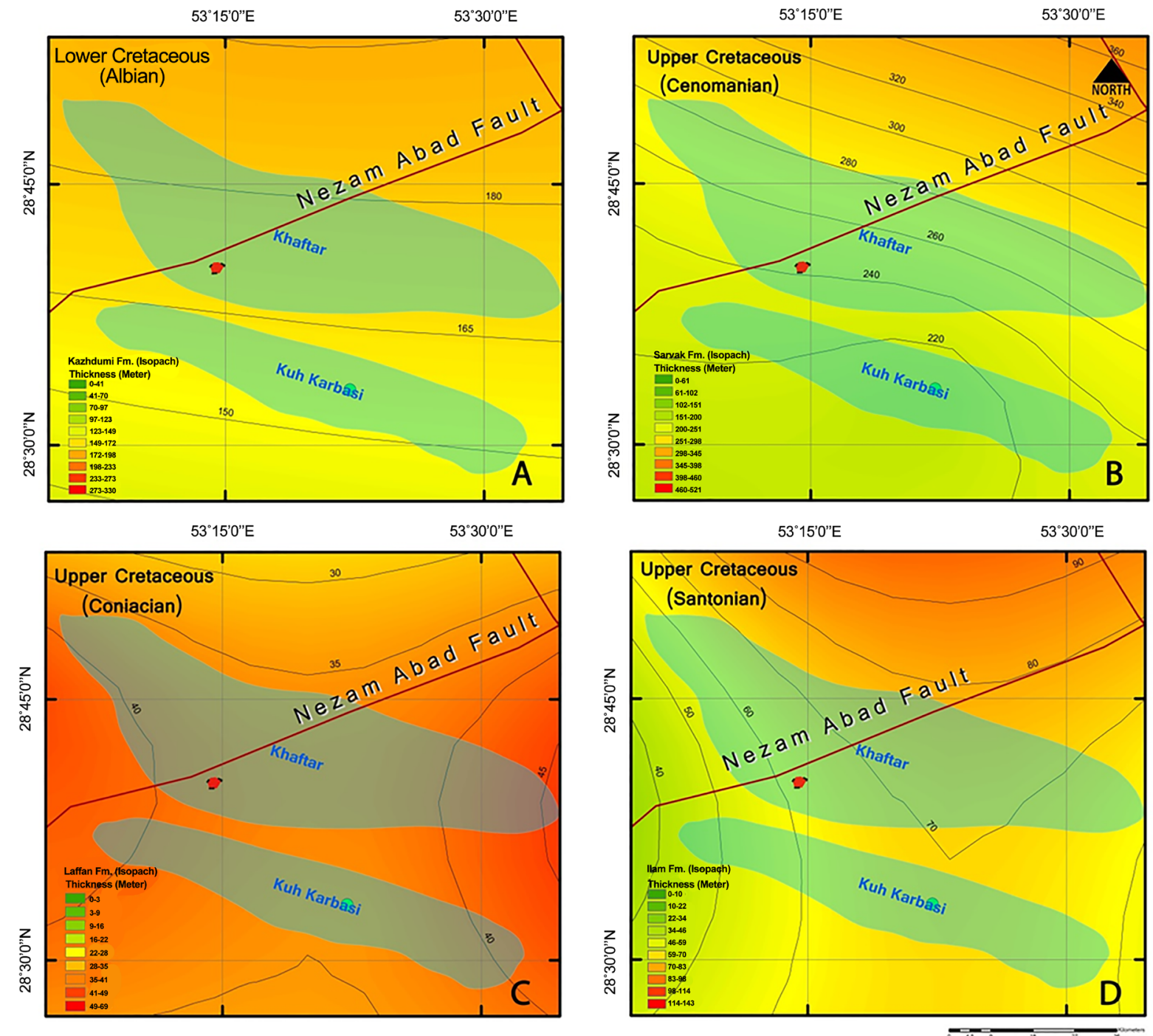

\section{Legend}

- Counties of Fars

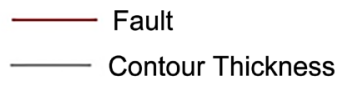

Zagros Structure

Figure 7. Isopach maps of formations in the study area around the Khaftar and Karbasi anticlines (from Lower Cretaceous (Albian) to Upper Cretaceous (Santonian): (A) Isopach Map of the Kazhdomi Formation (Lower Cretaceous, Albian); (B) Isopach map the Sarvak Formation (Upper Cretaceous, Cenomanian); (C) Isopach map of the Ilam Formation (Upper Cretaceous, Coniacian); (D) Isopach map of the Laffan Formation (Upper Cretaceous, Santonian). 


\subsection{Pabdeh and Gurpi Formations}

The Pabdeh Formation with Paleocene-Eocene age has changes in the study area and thickness from 100 to 200 meters. The Gurpi Formation (Campanian ageMaestrichtian) has a thickness variation from 150 meters to 400 meters. Based on Figure 8, toward the north, the thickness of the Gurpi Formation has been increased. Based, Isopach maps of the study area (Figure 8), thickness variations of the Pabdeh and Gurpi formations have not observed gradually and sudden changes in the thickness of these formations besides the Nezamabad fault. Therefore, it seems that, the Nezamabad fault has not activity in this timescales mentioned above and has not effect on the structure and hydrocarbon potential of the Khaftar and Karbasi anticlines. Based on the prepared Isopach maps may be tectonic process and the Nezamabad fault have been inactive during sedimentation of the Pabdeh and Gurpi Formation (Figure 8).

\section{Conclusions}

- The Nezamabad fault has been lacked of activity at the deposition time of the Dalan, Kangan, Dashtak, Fahliyan, Gadvan, Dariyan, Kazhdomi, Sarvak, Gurpi and Pabdeh formations within the Khaftar and Karbasi anticline area. Accordingly, changes in basin floor, at the time of sedimentation these formations has not been affected by the Nezamabad fault.

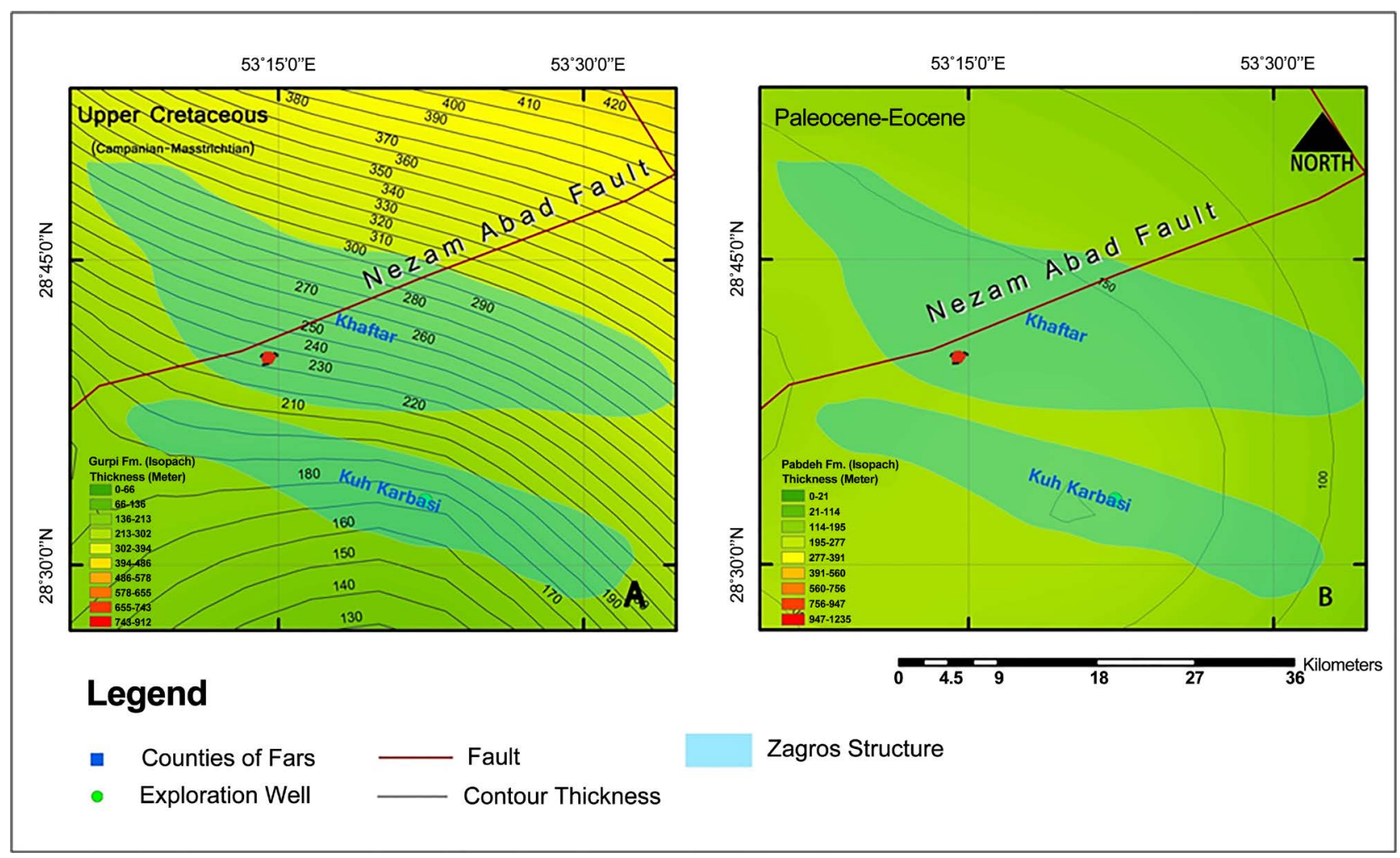

Figure 8. Isopach maps of formations in the study area around the Khaftar and Karbasi anticlines (from Upper Cretaceous (Campanian-Maastrichtian) to Paleocene): (A) Isopach Map of the Gurpi Formation (Upper Cretaceous, Campanian-Maastrichtian); (B) Isopach map the Pabdeh Formation (Paleocene-Eocene). 
- Probably the Nezamabad fault has been activated during deposition of the Surmeh, Hith, Laffan and Ilam formations and in this area paleo-basin has been controlled by this fault. In other words, it seems that, activity of the Nezamabad fault in this area have been limited to Jurassic and Cretaceous periods (Coniacian and Senomanian). This can means that in this periods time, the Nezamabad fault have been active sedimentation along with tectonic processes and activities affected on thickness of the Surmeh, Hith, Laffan and Ilam formations.

It seems that, Paleo-basin in the study area in the northern part has been under the influence of tensile forces and in the southern part by compressional force after uplift and sedimentation Hith formation. Possibly, with the compression force, sedimentation formation Gadvan has been continued in the relatively deep of the basin and continuity of operation of compression force has been created relatively deep conditions in the study area. Assuming proper expansion of organic matter in the basins of the study area is probably provided suitable conditions for source rock formation Gadvan. In the northern part of the study area, basin subsidence during sedimentation formations Kazhdomi and Sarvak probably has a positive effect on Hydrocarbon potential in the formation Gadvan Khaftar. However, it seems that Nezamabad fault activity, has been changed, Gadvan Formation hydrocarbon potential in the Khaftar.

The Kazhdomi Formation placed in relatively deep to support in this area could be the source rock properties in this formation. It seems that the Nezamabad fault and operation of uplift of the area, along with cropping out of the Khaftar salt plug in Khaftar anticline has led to outcropped Group Bangestan. Therefore, in general, it seems that the Bangestan reservoir horizons have no value in this area from hydrocarbon potential.

Finally, it seems that the Nezamabad Fault activity has been affected on the source rock, reservoir rock and cap rock and then controlled distributing of hydrocarbon system of the study area in the Khaftar and Karbasi as anticlinal oil traps.

\section{Acknowledgements}

The authors acknowledge the Department of geology, Islamic Azad University, Science and Research branch, Tehran, Iran for funded this project. In addition, we thank Vice-President for Research in Science and Research branch, Tehran.

\section{References}

[1] McQuarrie, N. (2004) Crustal Scale Geometry of the Zagros Fold-Thrust Belt, Iran. Journal of Structural Geology, 26, 519-535.https://doi.org/10.1016/j.jsg.2003.08.009.

[2] Afshar Barb, A. (2001) Petroleum Geology Chapters, Tehran University. Jahani, 2009.

[3] Barzegar, F. (1994) Basement Fault Mapping of Zagros Folded Belt (S.W. Iran) Based on Space-Born Remotely Sensed Data. Proceeding of the 10 th Thematic Conference on Geologic Remote Sensing. Exploration, Environment and Engineering, San Antonio, 9-12 May 1994, 455-466. 
[4] Maleki, Z., Arian, M., Solgi, A. and Ganjavian, M.A. (2014) The Elements of Fold Style Analysis in the Khaftar Anticline, Zagros, Iran. Open Journal of Geology, 4, 79-92. https://doi.org/10.4236/ojg.2014.43008

[5] Maleki, Z., Arian, M. and Solgi, A. (2014) Structural Style and Hydrocarbon Trap of Karbasi Anticline, in the Interior Fars Region, Zagros, Iran. Solid Earth Discussions 6, 2143-2167. https://doi.org/10.5194/sed-6-2143-2014.

[6] Maleki, Z. (2015) The Unique Folding Style in the Zagros Simply Folded Belt, the Kuh-e Qazi Anticline, South Iran. Open Journal of Geology, 5, 514-526. https://doi.org/10.4236/ojg.2015.57047.

[7] Maleki, Z. and Jahadgar, F. (2015) Folding Style of the Kuh-e Siah Anticline in the Sarvestan Area, Interior Fars, Zagros, Iran. Open Journal of Geology, 5, 552-561. https://doi.org/10.4236/ojg.2015.58050

[8] Baghbanan, A., Maleki, Z. and Pourkemani, M. (2015) Structural Style in the Khal-fani Anticline, Coastal Fars, Zagros Fold-Thrust Belt. Open Journal of Geology, 5, 655-665. https://doi.org/10.4236/ojg.2015.59058.

[9] Vaseghi, H., Maleki, Z. and Arian, M. (2016) Structural Style in the Zagros FoldThrust Belt: The Gavbast Anticline, Coastal Fars. Open Journal of Geology, 6, 109 116. https://doi.org/10.4236/ojg.2016.62011

[10] Hajnorouzi, N., Pourkemani, M. and Maleki, Z. (2016) Hydrocarbon Trap and Folding Style of the Pishvar Anticline, Sub-Coastal Fars, Zagros. Open Journal of Geology, 6, 376-386. https://doi.org/10.4236/ojg.2016.66033.

[11] Maleki, Z., Arian, M., Solgi, A. and Ganjavian, M.A. (2014) The Elements of Fold Style Analysis in the Khaftar Anticline, Zagros, Iran. Open Journal of Geology, 4, 79-92.

[12] Maleki, Z., Arian, M., Solgi, A. and Ganjavian, MA. (2013) Sediment Deformations on Strike Slip Fault Blocks and Analogue Modeling: A Case Study of Nezamabad Fault, Interior Fars, Zagros. Journal of Sciences (Islamic Azad University), 89, 39-51. (In Persian)

[13] Maleki, Z., Arian, M. and Solgi, A. (2015) Folding Pattern in the Fars Province, Zagros Folded Belt: Case Study on the Karbasi and Khaftar Anticlines, Interior Fars, Iran. Solid Earth Discussions, 7, 2347-2379. https://doi.org/10.5194/sed-7-2347-2015

[14] Maleki, Z., Arian, M., Solgi, A. and Ganjavian, M.A. (2015) Elements of Fold Style Analysis in the Karbasi Anticline, Interior Fars Region, Zagros. Geosciences, 24, 293-302.

[15] Falcon, N.L. (1974) Southern Iran: Zagros Mountains. In: Spencer, A., Ed., Mesozoic-Cenozoic Orogenic Belts, Data for Orogenic Studies: Alpine-Himalayan Orogens, Geological Society, London, Special Publications No. 4, 199-211.

[16] Berberian, M. and King, G.C.P. (1981) Towards a Paleogeography and Tectonic Evolution of Iran. Canadian Journal of Earth Sciences, 18, 210-265.

https://doi.org/10.1139/e81-019

[17] Berberian, M. (1995) Master "Blind" Thrust Faults Hidden under the Zagros Folds: Active Basement Tectonics and Surface Morphotectonics. Tectonophysics, 241, 193-224.

[18] Alavi, M. (2007) Structures of the Zagros Fold-Thrust Belt in Iran. American Journal of Science, 307, 1064-1095. https://doi.org/10.2475/09.2007.02

[19] Sepehr, M. and Cosgrove, J.W. (2004) Structural framework of the Zagros FoldThrust Belt, Iran. Marine and Petroleum Geology, 21, 829-843.

[20] Motiei, H. (1993) Stratigraphy of Zagros. Treatise on the Geology of Iran. Ministry 
of Mines and Metals, Geological Survey of Iran, Tehran.

[21] Esrafili Dizagi, B. and Rahimpour Bonab, H. (2013) A Review of Permo-Triassic Reservoir Rocks in the Zagros Area, SW Iran: Influence of The Qatar-Fars Arch. Journal of Petroleum Geology, 36, 257-279. https://doi.org/10.1111/jpg.12555

[22] Beydoun, Z.R., Hughes Clark, M.W. and Stoneley, R. (1992) Petroleum in the Zagros Basin: A Late Tertiary Foreland Basin Overprinted onto the Outer Edge of a Vast Hydrocarbon-Rich Palaeozoic-Mesozoic Passive-Margin Shelf. AAPG $\mathrm{Me}$ moir, 55, 309-339.

\section{Submit or recommend next manuscript to SCIRP and we will provide best} service for you:

Accepting pre-submission inquiries through Email, Facebook, LinkedIn, Twitter, etc. A wide selection of journals (inclusive of 9 subjects, more than 200 journals)

Providing 24-hour high-quality service

User-friendly online submission system

Fair and swift peer-review system

Efficient typesetting and proofreading procedure

Display of the result of downloads and visits, as well as the number of cited articles Maximum dissemination of your research work

Submit your manuscript at: http://papersubmission.scirp.org/

Or contact ojg@scirp.org 